\title{
Persistence of cytomegalovirus in mononuclear cells in peripheral blood from blood donors
}

\section{Department of \\ Biochemistry and \\ Molecular Genetics, St \\ Mary's Hospital Medical \\ School, London W2 \\ Philip Stanier, BSC, \\ research assistant \\ Nicholas Wales, Bsc, \\ research student}

Medical Research Council Collaborative Centre,

London NW7

Debra L Taylor, BSC, research assistan

A Stanley Tyms, PHD,

senior scientist

Department of

Microbiology, Regional

Blood Transfusion Centre,

Brentwood, Essex

CM15 8PD

Alan D Kitchen, MIBIOL,

senior scientific officer

Department of Medical

Microbiology, St George's

Hospital Medical School,

London SW17

Yvonne Tryhorn, FIMLS,

chief medical laboratory

scientific officer

Correspondence to: $\mathrm{Mr}$

Stanier.

Br Med f 1989;299:897-8
Philip Stanier, Debra L Taylor, Alan D Kitchen, Nicholas Wales, Yvonne Tryhorn, A Stanley Tyms

Human cytomegalovirus infection is common in the general population but generally remains silent; the risk of disease is greatest in fetuses and the newborn and in immunocompromised subjects. In addition to transmission of the virus by close physical contact iatrogenic infection occurs through blood transfusion and transplantation of organs.' Carriers of cytomegalovirus are normally identified from their antibody state, although the presence of virus can be detected by culture, assay for early antigens, or nucleic acid hybridisation. Most of these tests, however, are limited by their sensitivity or duration. The recent development of the polymerase chain reaction permits rapid and sensitive detection of viral genomes through specific amplification of DNA or RNA sequences. ${ }^{2}$ We used the reaction to determine the incidence of cytomegalovirus DNA in mononuclear cells from blood donors.

\section{Subjects, methods, and results}

Blood samples $(5 \mathrm{ml})$ were obtained from 30 blood donors attending the blood transfusion centre in Brentwood. The samples were typed for human cytomegalovirus with a total antibody detection kit (Abbott), and the mononuclear cell fractions, separated with Ficoll-Triosil gradients, were received in our laboratory with their antibody state coded. DNA was extracted from the cells by standard methods, and about $2 \%$ of each sample was analysed for the virus with the polymerase chain reaction. This was done, with positive and negative controls, essentially as described by Saiki et al. ${ }^{2}$ The primers ( 20 bases long) were specific to the immediate-early gene region exon $1,{ }^{3}$ and an oligonucleotide probe ( 17 bases long) internal to the product of the polymerase chain reaction was used to confirm the results by hybridisation (figure). We had previously characterised a gene probe to this region as highly conserved by reaction with 83 different isolates of human cytomegalovirus by Southern blotting and dot blotting (unpublished reports). The primers generated from the sequence to this region were specific for all of the 23 different isolates of cytomegalovirus we tested and did not amplify DNA sequences from humans, Escherichia coli, salmon sperm, adenovirus, simian-like cytomegalovirus (Colburn strain), Epstein-Barr virus, herpes simplex virus, or human herpes virus 6 .

Of the 30 samples of DNA from mononuclear cells tested, 25 were positive for cytomegalovirus by the polymerase chain reaction. When the antibody data were decoded we found that all of the samples negative by the polymerase chain reaction were negative for antibody but that five of the 25 samples positive by the polymerase chain reaction were negative for antibody. Three of the five subjects positive by the polymerase chain reaction but negative for antibody were retested after six months. The total antibody test (Abbott) used initially was repeated on the new samples, and another total antibody test (Compenz, Northumbria Biologicals) and an IgG detection test (Medac) were performed; all three tests gave negative results. Serum from these three subjects was also analysed by western blotting with antigens derived from cytomegalovirus AD169, and two of the samples were designated weakly positive. In all three subjects DNA from mononuclear cells remained positive by the polymerase chain reaction.

\section{Comment}

Several subjects considered not to be carriers of cytomegalovirus on the basis of their antibody state were found to be harbouring the virus in mononuclear cells in peripheral blood. Careful handling of the samples and rigorous controls ruled out contamina-
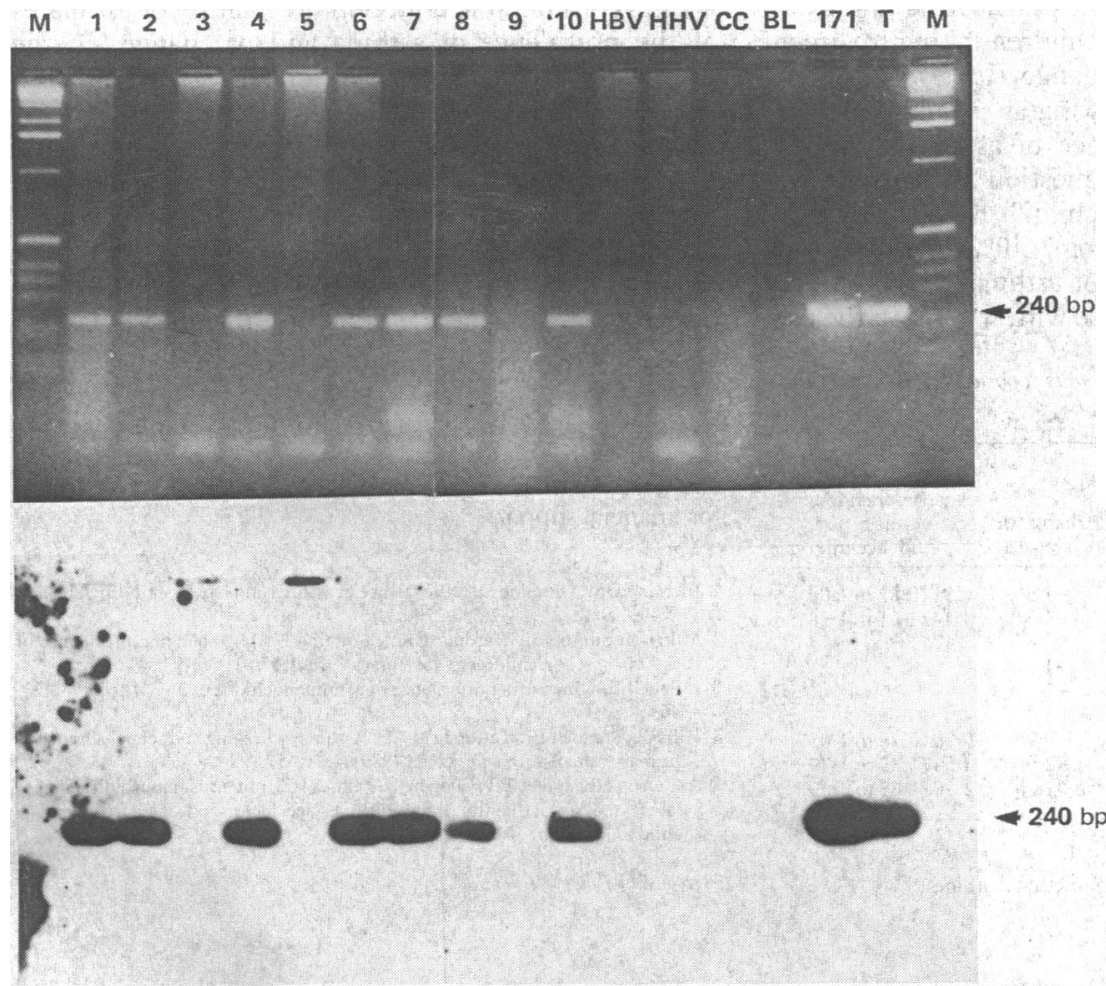

Products of polymerase chain reaction analysed on 3\% agarose gel stained with ethidium after 30 cycles of amplification (primer 1, 5'CCCGACTTTACCATCCAGTA3'; primer 2, 5'AAGACGAAGAGGAACTATCT3'). Lanes $1-10$ are results for mononuclear cells from blood donors (samples negative for antibody in lanes 1, 3, 5, 7, 8, 9); $E B V=E$ pstein-Barr virus); $H H V=$ human herpes virus $6 ; C C=$ cell $D N A$ control $; B L=$ blank of $D N A$ substituted by water; $171=$ cultured isolate of human cytomegalovirus; $T=$ Towne strain of human cytomegalovirus; $M=1$ kilobase ladder. 
tion. ${ }^{+}$Retesting of three of the five subjects negative for antibody but positive by the polymerase chain reaction confirmed the reproducibility of this technique.

Susceptible patients must be at some risk of infection when given transfusions of blood from subjects such as these who carry the virus. ${ }^{5}$ Thus the polymerase chain reaction clearly has an important role in screening blood products as well as being a powerful test in diagnostic virology.
1 Wilhelm JA, Matter L, Schopfer K. The risk of transmitting cytomegalovirus to patients receiving blood transfusions. I Infect Dis 1986;154:169-71.

2 Saiki RK, Gelfond DH, Stoffel S, et al. Primer-directed enzymatic amplification of DNA with a thermostable DNA polymerase. Science 1988;239:487-94.

3 Sternberg RM, Thomsen DR, Stinsky MF. Structural analysis of the major immediate early gene region of human cytomegalovirus. $\mathcal{F}$ Virol $1984 ; 49$ 190-9.

4 Kwok S, Higuchi R. Avoiding false positives with PCR. Nature 1989;339:237-8. 5 Yeager AS, Grumet FC, Hafleigh EB, Arvin AM, Bradley JS, Prober CG. Prevention of transfusion-acquired cytomegalovirus infections in newborn infants. F Pediatr 1981;98:281-7.

(Accepted 12 Fune 1989)

\section{Change in use of asthma as a diagnostic label for wheezing illness in schoolchildren}

\author{
Rosalind Hill, Jacky Williams, \\ Anne Tattersfield, John Britton
}

Respiratory Medicine Unit, City Hospital, Nottingham NG5 1PB

Rosalind Hill, BSC,

research assistant

Jacky Williams, research

technician

Anne Tattersfield, MD, professor

John Britton, $\mathrm{MD}$, lecturer

Correspondence to:

Ms Rosalind Hill.

Br.Med f 1989;299:898 1985 and 1988.

\section{Subjects, methods, and results}

The prevalence of asthma is reported to be rising in children and adults in the United Kingdom ${ }^{\prime 2}$ and in children in New Zealand. ${ }^{3}$ We previously argued that an important factor in this apparent increase may be an increase in the use of asthma as a diagnostic label for wheezing in children. ${ }^{4}$ In this study we looked at the change in the reporting of diagnosed asthma by parents of primary school children in Nottingham between

In 1985 we measured the prevalence of wheezing, reported asthma, and use of treatment for asthma in a questionnaire survey of the parents of all 4750 children in a random sample of 28 Nottingham primary schools. ${ }^{+}$ In 1988 we administered the same questions to the parents of all 17432 pupils in the 102 primary schools that had not been sampled in 1985. The age range of the children was 4 to 11 years in both studies. Completed questionnaires were received for $77 \%$ of the children in 1985 and $78 \%$ in 1988 .

Between 1985 and 1988 the crude prevalence of "wheeze ever" and wheeze in the past year, the frequency of reported episodes of wheezing in the past year, and the proportion of children taking treatment for asthma showed little change (table), with only wheeze in the past year showing an absolute increase $(1 \cdot 3 \%)$. The crude prevalence of asthma, however, reported in response to the question "What have you been told is wrong with your child?" increased by more than twice this amount, from $6.0 \%$ to $8.9 \%$. The increases in the prevalence of asthma, wheeze in the past year, and asthma in those with wheeze in the past

Prevalence of wheeze or asthma, or both, in schoolchildren in Nottingham as reported by their parents in studies in 1985 and 1988

\begin{tabular}{|c|c|c|c|c|}
\hline & \multicolumn{2}{|c|}{ No $(\%)$ of children } & \multirow[b]{2}{*}{$\begin{array}{c}\text { Change in } \\
\text { prevalence (\%) }\end{array}$} & \multirow{2}{*}{$\begin{array}{c}\text { Independent } \\
\text { odds ratio } \dagger \\
\text { (confidence interval) }\end{array}$} \\
\hline & $\begin{array}{c}1985 \\
(\mathbf{n}=3675)\end{array}$ & $\begin{array}{c}1988 \\
(\mathrm{n}=13544)\end{array}$ & & \\
\hline Wheeze ever & $651(17 \cdot 7)$ & $2224(16 \cdot 4)$ & $-1 \cdot 3$ & $0.91(0.82$ to 1.00$)$ \\
\hline Wheeze in past year & $424(11 \cdot 5)$ & $1738(12 \cdot 8)$ & $+1 \cdot 3$ & $1 \cdot 14(1.01 \text { to } 1.28)^{\star}$ \\
\hline Frequency: & & & & \\
\hline 1-4 Episodes & $263(62)$ & $1060(61)$ & -1 & \\
\hline$>4$ Episodes & $161(38)$ & $626(36)$ & -2 & \\
\hline Unspecified & 0 & $52(3)$ & +3 & \\
\hline Currently taking treatment for asthma & $253(6 \cdot 9)$ & $837(6 \cdot 2)$ & $-0 \cdot 7$ & $0.90(0.78$ to 1.05$)$ \\
\hline Asthma & $222(6 \cdot 0)$ & $1201(8.9)$ & $+2 \cdot 9$ & $1.54(1.32 \text { to } 1.79)^{\star \star \star}$ \\
\hline Asthma in those with wheeze in past year & $198(47)$ & $1137(65)$ & +18 & $2 \cdot 10(1.68 \text { to } 2.63)^{\star \star \star \star}$ \\
\hline
\end{tabular}

year among children aged 5-10 were significant after adjustment for differences in age and sex in a multiple logistic regression analysis.

\section{Comment}

Most studies of trends in the prevalence of asthma in children over time have measured the prevalence of disease reported by patients, parents, or doctors. We studied the prevalence of the symptoms and diagnosis of asthma and treatment for the disease on two occasions by identical methods in directly comparable populations. Within three years the prevalence of a reported diagnosis of asthma increased by nearly half. The prevalence of wheeze in the past year also increased significantly, but the magnitude of this increase was less than half that of the increase in reported asthma, and the change was not supported by comparable changes in the prevalence of wheeze ever or use of treatment.

The finding that the prevalence of reported asthma increased by so much more than the prevalence of other markers of the disease strongly suggests that much of the increase is attributable to a change in diagnostic labelling. Whether this reflects an increased willingness by parents to volunteer a diagnosis of asthma in their child or whether general practitioners now use asthma as a diagnostic label more commonly is not clear, though probably both of these factors have contributed. The increased use of asthma as a diagnostic label is unlikely to be due to an increase in the severity of symptoms as the distribution of frequency of wheeze in the two studies was similar.

The main practical importance of our finding is that it casts considerable doubt on the validity of estimates of the prevalence of asthma and of changes in the prevalence that are based solely on reports of diagnosed asthma. The fact that the prevalence of reported asthma increased without any significant change in the proportion taking treatment for the disease suggests that in this population of children at least the diagnostic label of asthma is not a major determinant of prescribing. Our findings indicate the need for objective measures in studies of the prevalence of asthma.

We thank Dr E J Hiller, Dr E More, Dr C Hopton, Mr A J Fox, and the many head teachers who advised us and cooperated with this study, and the Asthma Research Council for financial support.

\footnotetext{
1 Fleming DM, Crombic DL. Prevalence of asthma and hay fever in England and Wales. Br.Med 7 1987;294:279-83.

2 Morrison-Smith JM, Harding LK, Cumming G. The changing prevalence of asthma in schoolchildren. Clin Allergv 1971:1:57-61.

3 Mitchell EA. Increasing prevalence of asthma in children. NZ Med 7 1983;96: $463-4$

+ Hill RA, Standen PJ, Tattersfield AE. Asthma, wheezing and school absence in primary schools. Arch Dis Child 1989;64:246-51.

5 Anderson HR, Bailey PA, Cooper JS, Palmer JC. Influence of morbidity, illness label, and social, family and health service factors on drug treatment of childhood asthma. Lancet 1981;ii: 1030-2.
}

Accepted $1+7$ uly 1989 